\title{
ADAPTATION AND CHANGE IN ORGANIZATIONAL LEARNING RESEARCH
}

To understand the role of organizational learning in the organization's endeavor to overcome challenges, organizational learning research need to be spread out to the field of adaptation and change. This paper is the first part of a bigger empirical research, a literature review that examines the link between these topics and search for gaps in prior literature. However, these phenomena are closely related in the prior literature, the thinking about organizational learning is rather idealistic than reflective and there are still research gaps regarding the following questions: (1) Is there a need to examine internal organizational challenges from the organizational learning perspective? (2) How can the earlier organizational adaptation be characterized using the constructs of organizational learning? (3) Is the earlier adaptation process or organizational learning process always good and useful for the organization? Based on reviewing prior literature the author formulated an own organizational learning definition and identified future research directions in order to fill these gaps.

Keywords: organizational learning, adaptation, internal change, learning organization, intra-organizational challenges

\begin{abstract}
"We understand that the only competitive advantage the company of the future will have is its managers' ability to learn faster than their competitors."
\end{abstract}

This statement from a manager in Shell was quoted by Senge et al. (2014, p. 21.) in their work The Dance of Change. It highlights that the competitive value of learning and knowledge has grown. The ideas of both 'organizational learning' and the 'learning organization' have a positive and idealistic meaning in the existing literature. The common assumption is that learning in the organization is important and the main source of future competitive advantage. Although this is indisputable, we still lack a universal answer to the question of how learning really happens inside organizations. Learning has an important role in psychology research (Smith et al., 2005), includes different psychological perspectives (e.g. behavioral, cognitive and biological) and it is not only a conscious process. Therefore it is interesting question: If learning is so complex why are we so certain that it is always desirable for organizations?

The field of organizational learning overlaps with several research areas, for example, knowledge management, dynamic capabilities, ambidexterity, adaptation, and change management. In this paper, I examine organizational learning as an organizational adaptation process in entrepreneurial firms.

\section{Literature review}

\section{Adaptation in the existing literature}

A fundamental question of strategic management and organizational theory concerns the relationship between a firm and its environment. In particular, researchers want to know how an organization is able to react fast and efficiently to the changes and challenges of the environment, and how organizations evolve, adapt and change with their environment (Smith - Cao, 2007). Adaptation research examines this organization-environment relationship. Strategic adaptation means the organizational answers to environmental challenges (Szabó, 2012).

With the growth in competition, adaptation is crucial (Lawrence - Lorsch, 1967; Duncan, 1972). It is not enough to modify or recreate your strategy, the organization or its culture must change too. Organizations that are able to learn or self-adapt can succeed (Barakonyi, 2007). Thanks to the pressures from the changing environment, only dynamic organizations will be viable, and will have to change and adapt to survive (Szabó, 2008). 
Managers have the opportunity to react differently to environmental challenges under the same conditions (Dobák - Antal, 2010), but as well as the environment influencing the organization, the organization also influences its environment (Child, 1972; Dobák - Antal, 2010). Organizational adaptation and strategic behavior has long been the focus of international (Miles et al., 1978; Porter, 1993) and Hungarian (Antal-Mokos Kovács, 1998; Antal-Mokos - Tóth, 2001; Hortoványi - Szabó; 2006a,b; Szabó, 2008) strategic research communities. There are also several studies investigating the adaptation mechanisms and strategies of Hungarian companies during periods of environmental change, for example, during economic transformation (Balaton, 1999) the EU accession (Balaton, 2005) and the economic crisis (Balaton, 2011; Balaton - Csiba, 2012; Balaton - Gelei, 2013).

"Based on Burgelman's conceptualization (1983, 1991, 1996), major changes in an organization's strategy need not be completely governed by external selection processes. Successful renewal is likely to be preceded by internal experimentation and selection processes" (Hortoványi, 2012, p. 47.). Burgelman (1991) interpreted this internal experimentation and selection as an organizational learning process. This concept is related to the view of organizational ecology (Hannan - Freeman, 1989).

Smith and Cao (2007) distinguished three different perspectives in the relationship between firm and environment. Table 1 shows the comparison between (1) ecology, (2) adaptation and (3) entrepreneurial perspectives.

The ecology view (Hannan - Freeman, 1989) suggests that organizations are entirely dependent on their environment for survival. The adaptation perspective suggests that firms can adapt and change to some extent, in response to environmental change (Nelson Winter, 1982). The entrepreneurial perspective, by contrast, proposes that:

- through entrepreneurial actions, organizations can shape and influence their environments to their own benefit,

- top management has an important role in this process,

- the initial unit of analysis focuses on managers (Smith - Cao, 2007), and in particular "how top managers search, undertake firm actions, and learn to shape the environment" (Smith - Cao, 2007, p. 331.),

\section{Comparison of perspectives on the firm-environment relationship}

\begin{tabular}{|l|l|l|l|}
\hline & Ecology perspective & Adaptation perspective & $\begin{array}{l}\text { Entrepreneurial perspe- } \\
\text { ctive }\end{array}$ \\
\hline Theoretical focus & Environment selection & $\begin{array}{l}\text { Environment-induced va- } \\
\text { riation }\end{array}$ & Self variation \\
\hline $\begin{array}{l}\text { Assumptions: } \\
\text { Organizational structure } \\
\text { Organizational change }\end{array}$ & $\begin{array}{l}\text { Inertial } \\
\text { Random, accidental }\end{array}$ & $\begin{array}{l}\text { Path dependent } \\
\text { Reactive }\end{array}$ & $\begin{array}{l}\text { Malleable } \\
\text { Proactive }\end{array}$ \\
\hline Level of analysis & Industry/population & Firm & $\begin{array}{l}\text { Multilevel: managers to } \\
\text { firm to industry }\end{array}$ \\
\hline Timeframe of analysis & Long term & Middle term & $\begin{array}{l}\text { Multitime: short to medi- } \\
\text { um to long term }\end{array}$ \\
\hline Corresponding literatures & $\begin{array}{l}\text { Ecology } \\
\text { Resource dependency } \\
\text { theory }\end{array}$ & $\begin{array}{l}\text { Fit } \\
\text { Competitive dynamics } \\
\text { Innovation as adaptation }\end{array}$ & $\begin{array}{l}\text { Sensemaking } \\
\text { Social cognition } \\
\text { Entrepreneurial action }\end{array}$ \\
\hline $\begin{array}{l}\text { Firm-environment re- } \\
\text { lationship }\end{array}$ & $\begin{array}{l}\text { Random variations by the } \\
\text { individual firms are selec- } \\
\text { ted by the environment. } \\
\text { Over time, firms conform } \\
\text { to the industry trend. The } \\
\text { industry evolves through } \\
\text { the birth and demise of } \\
\text { individual firms. }\end{array}$ & $\begin{array}{l}\text { Individual firm search } \\
\text { to resolve misfit with the } \\
\text { follow path-dependent rou- } \\
\text { tines and enable them to } \\
\text { return to the fit condition. }\end{array}$ & $\begin{array}{l}\text { Managers driven by belief } \\
\text { systems engage the firm } \\
\text { in entrepreneurial actions, } \\
\text { which not only change } \\
\text { their own belief systems, } \\
\text { but also potentially chan- } \\
\text { ge the market belief sys- } \\
\text { tems. }\end{array}$ \\
\hline
\end{tabular}


- the goals of each search and associated action are not taken as given, and that their adjustment is an important part of the dynamic change process. The process is therefore similar to Argyris and Schön's (1978) double-loop learning (Smith - Cao, 2007), while the adaptation perspective is akin to single-loop learning. Unlike the other two perspectives, this one includes double-loop learning but focuses only on the belief system changes regarding the external environment.

There are several works that recognize adaptation directly related to the concept of learning (Crossan et al., 1999; Eisenhardt - Martin, 2000; Zollo - Winter, 2002; Easterby-Smith - Prieto, 2008). Other important contributions include:

- Senge et al. (2014, p. 24.) claimed that "All organizations learn - in the sense of adapting as the world around them changes",

- adaptation to the continuously changing environmental conditions is linked to the continuous learning of the organization and the continuous development of learning capabilities (Bakacsi, 1999), and

- Jyothibabu et al. (2010) defined organizational learning as adaptation to the changes in operational culture, development of new ways of doing things, norms and paradigms.

It is clear from the literature that adaptation and learning are closely related. Adaptation research investigates the ability of an organization to change in response of external challenges. In my interpretation, to understand the adaptation-learning relationship, I must first examine the links between learning and change.

\section{Link between learning and change}

Learning by definition is linked to change. According to Bakacsi (2004), learning is a permanent change in behavior that is the result of experience. Organizational learning can therefore be defined as a change in the behavior of the organization (Fiol - Lyles, 1985): transformation of decision-making processes, or changes in the organizational members' routines that result in improvements in individual and organizational performance (Bakacsi, 1999). Senge et al. (2014, p. 9.) quoted from Nitin Nohria that "inadequate learning capabilities limit most change initiatives". Bontis et al. (2002, p. 9.) differentiate between:

- feed-forward learning: whether and how individual learning feeds forward into group learning and learning at the organizational level (e.g. changes to structure, systems, products, strategy, procedures, culture),

- feedback learning: whether and how the learning that is embedded in the organization (e.g. systems, structure, strategy) affects individual and group learning.

According to Bontis et al. (2002) learning happens at different levels and starts at the individual level. Moreover there is interaction between these levels and this interaction also results in change. These ideas suggest that it is worth examining the linkage between learning and change.

Change, however, can be interpreted in several ways, often contradictory (Senge et al., 2014):

- external changes in technology, customers, competitors, market, structure, or the social and political environment,

- internal changes: how the organization adapts to changes in the environment, and

- top-down programs, including reorganization and reengineering.

I believe that I first need to distinguish external and internal changes. External changes are outside the organizational borders. Internal changes are harder to define, not least because we can identify different aspects of them, for example:

- individual vs. organizational,

- at process/task level vs. strategic level,

- emergent/autonomous vs. induced (Burgelman 1991),

- episodic vs. continuous (Weick - Quinn, 1999),

- incremental vs. radical (Dobák - Antal, 2010), and

- cognitive vs. behavioral.

I do not wish to draw a comprehensive picture of change, but simply to highlight that the different meanings and interpretations of change can result in confusion in learning research. Table 2 shows the most relevant change types, compared by their distinguishing features and link to learning research.

Table 2 shows that:

- individual-level change can be linked to individual learning, and organizational change to organizational learning,

- double-loop learning shows up in the literature around changes in the cognitive map and on the strategic level, and

- internal non-strategic organizational-level changes (in processes, routines, behavior) are mostly related to single-loop learning. The double-loop learning aspect is missing from these studies. 


\section{Different typologies of internal organizational change and their links to learning research}

\begin{tabular}{|c|c|c|c|}
\hline Types of change & Distinguishing feature & \multicolumn{2}{|c|}{ Link to learning research } \\
\hline $\begin{array}{l}\text { Individual vs. } \\
\text { organizational change }\end{array}$ & $\begin{array}{l}\text { Level and extensiveness of } \\
\text { change }\end{array}$ & \multicolumn{2}{|c|}{ Individual-level vs. organization-level learning } \\
\hline $\begin{array}{l}\text { Process level vs. } \\
\text { strategic change }\end{array}$ & $\begin{array}{l}\text { Focus of change (internal } \\
\text { or external change and } \\
\text { challenges) }\end{array}$ & \multicolumn{2}{|c|}{$\begin{array}{l}\text { Single-loop learning in routines as internal, process level } \\
\text { change. Double-loop learning in strategy induced by } \\
\text { external challenges, changes in the environment. }\end{array}$} \\
\hline $\begin{array}{l}\text { Emergent vs. induced } \\
\text { changes }\end{array}$ & $\begin{array}{l}\text { Direction and } \\
\text { consciousness of change }\end{array}$ & \multirow{3}{*}{$\begin{array}{l}\text { Emergent/ Continuous/ } \\
\text { Incremental change: } \\
\text { Basic territory of } \\
\text { organizational learning } \\
\text { research and the Learning } \\
\text { School }\end{array}$} & \multirow{3}{*}{$\begin{array}{l}\text { Induced/Episodic/ Radical } \\
\text { change: } \\
\text { No or just minor focus on } \\
\text { this topic in organizational } \\
\text { learning research. The field } \\
\text { of change management }\end{array}$} \\
\hline $\begin{array}{l}\text { Continuous vs. episodic } \\
\text { change }\end{array}$ & Periodicity of change & & \\
\hline $\begin{array}{l}\text { Incremental vs. radical } \\
\text { change }\end{array}$ & $\begin{array}{l}\text { Quality of change at } \\
\text { organizational level }\end{array}$ & & \\
\hline $\begin{array}{l}\text { Cognitive vs. } \\
\text { behavioral change }\end{array}$ & $\begin{array}{l}\text { Quality of change at } \\
\text { individual level }\end{array}$ & \multicolumn{2}{|c|}{$\begin{array}{l}\text { Two types of double-loop learning. More focus on the } \\
\text { changes in cognitive maps. }\end{array}$} \\
\hline
\end{tabular}

Source: own work

In this paper, I will use the evolving change construct for emergent, continuous, and incremental changes, and the intentional construct for induced, episodic, and radical changes. Angyal (2009) examined the nature of changes, including undirected changes. He claimed that undirected changes can also be radical. I do not, however, wish to investigate these types of changes, which are mostly found in crisis situations.

\section{Evolving change and learning}

Mintzberg et al. (2009) described ten different schools of strategy, one of which is the Learning Schools. This looks at strategy as an emergent process. The antecedents of this school are disjointed and logical incrementalism and the evolutionary theory, resulting in a view of strategy as emergent, experimental and reflective. From the Learning School perspective, organizational learning has a huge role in the adaptation process of an organization. According to Szabó (2012, p. 17.), "strategic adaptation is one main question of the Learning School, which cannot be measured through classic financial indicators but mainly through the capability of knowledge creation and retrieval".

Organizational learning includes the following statements based on the assumptions of evolutionary theory (Mintzberg et al., 2009):

- routines are responsible for creating change,

- the interaction between established routines and novel situations is an important source of learning, and

- the concept of emergent strategy opens the door to strategic learning because it acknowledges the organization's capacity to experiment.
The Learning School declares that deliberate strategy focuses on control, while emergent strategy emphasizes learning, and uses organizational learning to adapt to changes in operational culture. The Learning School therefore defines organizational learning as an emergent, incremental adaptation process, containing incremental change.

These declarations raise the question of whether learning as an adaptation is always an emergent, incremental and experimental change process, but not radical and induced. According to Noszkay (2008), incremental changes face less resistance and result in less subjective loss, but they are usually not suitable for solving systemic organizational problems. I suggest that organizational learning includes radical, systemic change as well. In the following section, I examine the relationship between learning and this type of change.

\section{Intentional change and learning}

Jyothibabu et al. (2010) contended that learning and change are not only parallel and simultaneous, but also interactive processes, as learning has a mediating role in the change process. They also presumed that there is constant interaction between the individual and structural levels. Reaching a structural level in the learning process means, in practice, structural changes, which in turn affect the individual level and call for more individual learning. Structural changes are the result of intentional change.

Weick and Quinn (1999) drew a distinction between two kinds of changes, episodic and continuous. They defined episodic changes as a form of short-term adaptation. Episodic change is most closely associated with 
planned, intentional change that can be characterized by the Lewinian approach (unfreeze, transition, refreeze):

\begin{abstract}
"Intentional change occurs when a change agent deliberately and consciously sets out to establish conditions and circumstances that are different from what they are now and then accomplishes that through some set or series of actions and interventions either singularly or in collaboration with other people" (Ford-Ford, 1995, p. 543.).
\end{abstract}

Dobák and Antal (2010) differentiated between radical and incremental change. Radical change is extensive and induced by the top management, and has influence on the whole or the majority of the organization. It is quite fast and means systemic change at all levels of the hierarchy.

In the organizational ecology view (Burgelman, 1991), there are two kinds of adaptation, induced and autonomous. I suggest that these are change processes. In the induced type, organizational learning comes up in the retention phase, and is about bases for past or current survival. "Firms are able to overcome the liabilities of newness by accumulating and leveraging organizational learning, and by deliberately combining distinctive competences in the induced process" (Burgelman, 1991, p. 254.). I regard episodic, induced and radical changes as intentional change induced by the management of the organization.

The territory of intentional changes is the field of change management research, and organizational learning research also has unanswered questions in this field. Most of the research on organizational learning as organizational development focuses on learning as an evolving change process. There are, however, some researchers who suggest that it is important to examine learning in intentional change.

According to Dobák and Antal (2010), intentional organizational change is an iterative, learning process. Change managers have to manage this learning process, which includes their own learning as well the learning of the organizational members and the whole organization. Senge et al. (2014), in their book The Dance of Change, used the word profound for radical change. They claimed that there is learning in profound change, and describe it as an incorporation of both an internal shift in people's values, aspirations, and behaviors, and external changes in the fundamental thinking patterns of organizations that underlie choices of strategy, structures, and systems. They declared that it is not enough to change strategies, structures, and systems, unless the thinking that produced those also changes. This type of change therefore involves a learning process with the same characteristics as double-loop learning.
Levinthal and Rerup (2006) introduced the constructs of 'mindful' and 'less-mindful' approaches to learning. They claimed (Rerup - Levinthal, 2013) that these approaches are relatively established in the existing literature. For example the less-mindful approach is set out in the work of March and Simon, (1958), Cyert and March, (1963) and Nelson and Winter (1982), and the mindful approach in the work of Weick and Roberts (1993) and Weick et al. (1999). The less-mindful approach is related to evolving change while the mindful one is more about intentional change. Rerup and Levinthal (2013, p. 44.) suggested that:

"organizational learning must incorporate both perspectives in a broader synthesis to better understand where the benefits of less mindful processes ends and the benefits of more mindful processes begins (or vice versa), and whether the two phenomena intersect, interact, or operate in parallel."

They also proposed that these should not be regarded as separate or parallel but co-constitutive phenomena and concluded "today we know about how the co-constitutive relationship between the two phenomena unfolds and influences organizational learning and change across a system". Bakacsi (2010) differentiated between first- and second-order change, the interpretation of single- and double-loop learning in change management literature. He pointed out that change needs a change agent or leader, who chooses between first- or second-order change.

It is clear that intentional and evolving change can result in different learning processes. I assume that the interpretation of adaptation and organizational learning has a key role in examining organizational learning. In the next section, I set out the research gap linked to these topics.

\section{The relation between change, adaptation and learning}

I want to find an answer to the emergent mixture of entrepreneurial adaptation, change and learning. Previous efforts to grasp the phenomenon of organizational learning have mixed together change, learning, and adaption, with only casual attention to levels of analysis (Weick, 1991).

Figure 1 is a simplified version of Table 2, which tries to relate adaptation, change and learning. Based on this model, I have formulated the following propositions:

- Evolving change bears the marks of the adaptation perspective (Smith - Cao, 2007), while intentional 
change is much more related to the entrepreneurial adaptation perspective (Smith - Cao, 2007).

- Adaptation research focuses on changes in strategy linked to the environment-organization relationship. The internal processes of the organization are not in its main focus.

- Evolving change in the internal organization is the main field of organizational learning research. This can be characterized as an emergent and incremental experimentation process (Mintzberg et al., 2009).

- The field of intentional change at intra-organizational process level is not the main focus of adaptation or organizational learning research. It is therefore an interesting area for entrepreneurial and organizational learning research.

- Intentional change needs double-loop learning.

Figure 1

Adaptation, learning and organizational change

\begin{tabular}{|c|c|c|}
\hline & Evolviug change & Iutcutional change \\
\hline Change in strategy & Adaplation perspective & $\begin{array}{l}\text { Lintrepremeurial } \\
\text { perppective }\end{array}$ \\
\hline $\begin{array}{c}\text { Change at proceis } \\
\text { Iercl }\end{array}$ & $\begin{array}{l}\text { Fmergent, incremental } \\
\text { orgenizational lewming }\end{array}$ & Change manapement \\
\hline
\end{tabular}

Source: own work

There is a gap in the organizational learning literature. Organizational learning is an internal adaptation process induced by the environment, but the adaptation literature does not focus on internal processes.

According to Mészáros (2010, 2011), research and strategic thinking in the 1990s focused on questions about how past practice and processes can create patterns that shape the present and the future. That resulted in an exploitation and internal focus. Strategic management was criticized for having too much focus on present performance, and only a weak relation to the future. Entrepreneurship research, however, focuses on opportunity-seeking and has a dominant future-oriented perspective (Dobák - Hortoványi - Szabó, 2012). It therefore results in a dominant future-oriented approach in entrepreneurial adaptation.

Entrepreneurial firms focus on environmental challenges and future trends and changes. This is, of course, crucial in survival and in competition, but shifts the focus of the entrepreneur to the external environment and the future. This does not force the entrepreneur to (1) seek challenges inside the organization, (2) question the earlier adaptation processes of the organization and (3) assess whether past organizational adaptation was always well-managed. This can result in biased adaptation.

According to Rerup and Levinthal (2013, p. 39.):

"Organizational actions are history-dependent, and the behavior in an organization is based on routines. Routines are based on interpretations of the past more than anticipations of the future. They adapt to experience incrementally in response to feedback about outcomes."

Future-oriented adaptation can therefore generate change in cognition and thinking, but behavioral changes will be dominated by the past. Cognitive change without behavioral change will not lead to success.

I suggest that organizational learning is a form of adaptation. The interesting question is whether organizational learning research provides answers to the following questions:

- Is there a need to examine internal organizational challenges from the organizational learning perspective?

- How can the earlier organizational adaptation be characterized using the constructs of organizational learning?

- Is the earlier adaptation process or organizational learning process always good and useful for the organization?

To answer these questions, I examine the existing organizational learning definitions, perspectives, and models. My aim is to understand whether the dominant future-oriented and external focus is also present in organizational learning research.

\section{Adaptation in organizational learning research}

\section{Review of organizational learning definitions and perspectives}

A difficulty in investigating organizational learning is that there is no unified definition of it. Bontis, Crossan and Hulland (2000) collected together different definitions of organizational learning from the literature. There are differences in the focus of these definitions. Some highlight the process character of organizational learning (Argyris - Schön, 1978; Fiol - Lyles, 1985; Stata, 1989; Lee et al., 1992; Crossan et al., 1999). Others focus on changes in behavior (Levitt - March, 1988; Huber, 1991; Slater - Narver, 1995) or the shared nature of learning and knowledge in the organization (Cavaleri - Fearon, 1996; Schwandt - Marquardt, 2000).

Some studies have tried to capture the different aspects and concepts within this phenomenon, and from 
these, I have chosen to focus on the work of Shrivastava (1983). Shrivastava (1983) developed four different concepts of organizational learning, viewing it as (1) adaptation, (2) assumption-sharing, (3) developing knowledge of action-outcome relationships, (4) and institutionalized experience.

The first perspective, adaptive learning, has an external, environmental focus, which does not deal with the adaptation processes at the level of organizational processes and practices. The adaptation takes place only at the level of goals, search and attention rules, and in strategic thinking. The second perspective is about assumption-sharing and change in the theories driving these assumptions. It includes double-loop learning at the cognition level, but does not deal with behavioral changes or rethinking organizational processes. The last two focus on the content of learning, knowledge and experiences rather than the process of learning. This differentiation shows that the perspectives of organizational learning cover the cognitive and behavioral questions and the content and process in different ways. Organizational learning as adaptation is an environment-focused question with strategic level change, but without any aspects of internal organizational operation and processes.

Hortoványi and Szabó (2006c) applied a similar differentiation of organizational learning perspectives. Their first two perspectives are the same as in Shrivastava's (1983) work. The third is resource-based learning, which introduced the knowledge-based theory of the firm (Nelson - Winter, 1982; Stein, 1995). The fourth perspective introduced the concept of the 'learning organization' (Senge, 1990).

Gelei $(2002,2005)$ had a different approach to the organizational learning phenomenon. He set up three interpretations of organizational learning. The first is the process of embedded practical knowledge community formation. This approach interprets learning at the level of communities-of-practice, as a social construction process. The second is a new organizational logic that emerges in the dialogic process between dominant and innovation logic. This concept focuses on the future-oriented, innovation capabilities of the organization. The last is action learning and growing organizational self-control based on the reflective re-evaluation of organizational experiences. The last approach assumes learning is a reflective process. Gelei (2002, 2005) did not, however, evaluate whether the reflection results are strategically useful for the organization, but takes reflection as a common reality and critical interpretation of organization members.

\section{The Learning Organization}

Proper knowledge management and learning are only possible in an environment where continuous learning and experimenting are greatly valued, appreciated and supported (Garaj, 2008). The Learning Organization concept engages in the question of how to establish conditions for future competitive advantage, and to survive in the present, through learning. 'Organizational learning' and the 'learning organization' are often used as synonyms, but based on their definitions, they are not the same. According to Yeo (2005, p. 369.):

"Organizational learning is a process which
answers the question of "how"; that is, how is
learning developed in an organization? The term
"organizational learning" is used to refer to the
process of learning. On the other hand "learning
organization" is a collective entity which focus-
es on the question of "what"; that is, what are
the characteristics of an organization such that
it (represented by all members) may learn? The
"learning organization" embraces the impor-
tance of collective learning as it draws on a larger
dimension of internal and external environments.
The idea of "learning organization" refers to a
type of organization rather than a process."

To understand the learning organization concept fully, I examined Senge's (1990) and Garvin's (1993) works.

To establish a learning organization, Senge (1990) proposed five criteria:

- Systems thinking: This highlights the importance of interdependence and integrity. A system cannot be redesigned by dividing it into parts; it calls for collaboration and systematic thinking.

- Personal mastery: "Organizations learn only through individuals who learn. Individual learning does not guarantee organizational learning. But without it no organizational learning occurs" (Senge, 1990, p. 139.). This factor means the organization's members' capability for learning.

- Mental models: Mental models are beliefs, mindsets, values and assumptions that determine the way people think and act.

- Shared vision: Shared vision is not only a belief. It focuses on mutual purpose and sense of commitment.

- Team learning: Team learning is a process by which capabilities of group members increase. This learning is based on shared vision.

Steiner (1998) stressed that the relationship between the five disciplines and the way each affects the others, need to be closely examined. 
According to Garvin (1993), learning organizations can be characterized by five main activities: (1) systematic problem-solving, (2) experimenting, (3) learning from past experience, (4) learning from others and (5) passing the knowledge on to others fast and efficiently. These can enhance capacity to obtain knowledge, and alter behavior based on knowledge and insight. Of the five, systematic problem-solving and learning from past experience are perhaps the most crucial.

According to Garvin (1993), an organization that learns possesses the ability to analyze problems systematically, based on data and going beyond the obvious symptoms to explore the underlying causes. He claimed that otherwise "the organization will remain a prisoner of 'gut facts' and sloppy reasoning, and learning will be stifled" (Garvin, 1993, p. 54.). This is not a classical, data-based analysis, but an ability to understand the hidden factors, the big picture and the systemic failures. I believe that without this, double-loop learning will be stifled, and the wrong conclusions will generate the wrong routines, fixing the underlying causes into organizational routines.

Garvin (1993) also proposed that companies must review and assess their success and failures systematically and have to record lessons from this assessment. This is close to the re-evaluation of past learning processes that is an important part of organizational learning.

In my view, the Learning Organization concept is functional only in an organization which does not suffer from previous failures to adapt and learn. This concept is future-oriented, asking the question what should the organization do to be able to continuously learn?, but does not question whether learning is always useful to the organization. The underlying assumption is that learning enhances organizational abilities and is always desirable for the organization.

Nonaka (2007, p. 164.) claimed that "the knowledge-creating company is as much about ideals as it is about ideas: to create new knowledge means quite literally to recreate the company and everyone in it in a nonstop process of personal and organizational self-renewal". I want to focus on the dominant idealistic thinking about organizational learning and learning organizations in the literature. The work of Garvin (1993) identified similar issues, which I believe are missing from most organizational learning research, but they are not yet in an integrated framework.

Reviewing the learning organization models, I suggest that these concepts show an idealistic picture of organizational learning. On the phrase idealistic I understand that they try to explain the factors that are needed to reach the ideal learning organizational state but do not deal with the change process, how an organization can become a learning organization and the facilitators and inhibitors in this process. I assume that this kind of thinking has roots in the dominant future-oriented adaptation, resulting in less thinking about previous adaptation and learning processes, which can have a huge effect on future ability to learn.

\section{Research gap in organizational learning literature}

Lähteenmäki et al. (2001, p. 118.) made a critique of organizational learning research. They claimed:

\begin{abstract}
"The literature regarding both learning organizations and organizations learning is largely prescriptive in nature and proposes how organizations should be designed and managed in order to promote effective learning. There is (a) lack of conceptualization of the true nature of (the) organizational learning process."
\end{abstract}

This prescriptive characteristic can be traced back to future- and environment-oriented entrepreneurial adaptation. The dominant focus of adaptation results in a similar focus to organizational learning research. It also diverts the direction of research from examining past learning and existing routines to learning in the future. I therefore suggest a more integrated interpretation of organizational learning as an adaptation process, incorporating single and double-loop learning, internal and external adaptation and changes in cognition and behavior.

Routine is one basic category of organizational learning, covering the accumulated organizational capabilities, rules, and historically-evolving patterns of behavior that can be seen in the predictable and habitually recurrent behavior of organizational members (Gelei, 1993). The routine is a part of the activity called organizational memory. Routine generates single-loop learning at the organizational level (Bakacsi, 1999). Real organizational change only takes place with organizational learning when there is change in the organization's cognitive map. This is double-loop learning at organizational level. According to Bakacsi (1999), double-loop learning does not need constant changes in the organization's cognitive map. Instead, it is much more the capability of the organization (its members and managers) to identify these frameworks and be able to question them.

Single-loop learning is the general learning method of organizations at process level. This can be characterized as a type of behavioral learning at the level of routine creation. Real organizational change, however, can only be a source of double-loop learning, and in the literature, mostly means change in cognition, or cognitive maps. The adaptation paradox, the dominant 
future- and external environment orientation, calls attention to the following:

- The future-oriented and external focus diverts attention from examining double-loop learning at the level of processes, structures and routines, which involve behavioral change and learning.

- Single- and double-loop learning are related to each other in both cognitive and behavioral change. It is therefore worth examining these phenomena together to get a more holistic picture of organizational learning as an adaptation process.

To highlight my organizational learning interpretation, I formulated my own organizational learning definition partly based on different existing definitions:

Organizational learning is an organizational ability and process of change in cognition and behavior, using both single-loop and double-loop processes. It is based on the organizational members' (individual) learning and individual and organizational level learning are in interaction. It includes interpreting and revaluating past experiences and actions, understanding current organizational performance and environmental factors, and generating new knowledge to grow and survive in the future. Organizational learning is therefore a process of adaptation to internal and external challenges.

Table 3 summarizes the existing focus of organizational learning research and identifies a new focus to fill a gap in the literature.

Table 3

\section{Existing and new foci in organizational learning}

\begin{tabular}{|l|l|}
\hline Existing focus & New focus \\
\hline $\begin{array}{l}\text { Adaptation to external } \\
\text { environmental challenges }\end{array}$ & $\begin{array}{l}\text { Adaptation to intra- } \\
\text { organizational challenges }\end{array}$ \\
\hline External focus & Internal focus \\
\hline Change in strategy & $\begin{array}{l}\text { Change in intra- } \\
\text { organizational process }\end{array}$ \\
\hline Through evolving changes & Through intentional changes \\
\hline New knowledge creation & $\begin{array}{l}\text { Existing knowledge re- } \\
\text { evaluation }\end{array}$ \\
\hline Learning in cognitive change & $\begin{array}{l}\text { Learning in cognitive and } \\
\text { behavioral change }\end{array}$ \\
\hline
\end{tabular}

Source: own work

\section{Conclusion}

This paper is a comprehensive literature review in investigating the link between organizational learning, adaptation and change. My aim with this paper was to understand and explore prior literature and potential research gaps. Organizational learning research has a dominant future-oriented perspective because of the thinking on adaptation. Research on both adaptation and organizational learning has not examined the path-dependency factors in adaptation, so that adaptation and learning in the past and their effect on the present and future have not been the focus of researchers. This kind of research, in my opinion, seeks ideal ways to adapt and learn and does not deal with what is really happening inside organizations. I therefore suggest to keep these thoughts to the fore and use a more critical perspective to examine organizational learning. I propose that the explored gap in literature needs to be investigated in order to answer the defined research questions and to deeply understand organizational learning processes and change in entrepreneurial firms.

Managing change and learning challenges organizations. The understanding the role of learning in change and organizational adaptation can help practitioners in recognizing the organizational learning processes and their results inside the organization, as well it can support managers in enhancing the organizational ability to change and learn in reply to the internal organizational challenges induced by organizational growth and external challenges of the changing environment.

\section{References}

Angyal, Á. (2009): Változások irányítás nélkül. Vezetéstudomány (Budapest Management Review), 40(9): p. 2-16.

Antal-Mokos, Z. - Kovács, P. (1998): Magyar vállalati stratégiák az 1990-es évek első felében - taxonómia. Vezetéstudomány (Budapest Management Review), 29(2): p. 23-34.

Antal-Mokos, Z. - Tóth, K. (2001): Vállalati stratégiák Magyarországon 1990-es évtizedben. Vezetéstudomány (Budapest Management Review), 32(1): p. 21-30.

Argyris, C.-Schon, D.A. (1978): Organizational Learning: A Theory of Action Perspective. Reading, MA.: Addison-Wesley

Bakacsi, Gy. (1999): Szervezeti magatartás és vezetés. Budapest: Aula Kiadó

Bakacsi, Gy. (2004): Szervezeti magatartás és vezetés. Budapest: Aula Kiadó

Bakacsi, Gy. (2010): Managing Crisis: Single-Loop or Double-Loop Learning? Strategic Management, 15(3): p. 3-9.

Balaton, K. - Csiba, Zs. (2012): A gazdasági válság hatása a vállalati stratégiákra - magyar és szlovák tapasztalatok. Vezetéstudomány (Budapest Management Review), 43(12): p. 4-13. 
Balaton, K. - Gelei, A. (2013): A gazdasági válság hatása a szervezetek múködésére és vezetésére. Economic Review, 60(3): p. 365-369.

Balaton, $K$. (1999): Organization studies in Hungary. Organization Studies, 20(4): p. 711-714.

Balaton, K. (2005): Attitude of Hungarian companies towards challenges created by EU-accession. Journal for East European Management Studies, 10(3): p. 247-258.

Balaton, K. (2011): Possible Enterprise Strategies After the Economic Crisis. Journal of Business Management, 4: p. 121-128.

Barakonyi, K. (2007): Metaforák a stratégiaalkotásban. Vezetéstudomány (Budapest Management Review), 38(1): p. 2-10.

Bontis, N. - Crossan, M. M. - Hulland, J. (2002): Managing an organizational learning system by aligning stocks and flows. Journal of Management Studies, 39(4) p. 437-469.

Burgelman, R. A. (1996): A process model of strategic business exit: Implications for an evolutionary perspective on strategy. Strategic Management Journal, 17(special issue): p. 2193-2214.

Burgelman, R. A. (1983): A model of the interaction of strategic behavior, corporate context, and the concept of strategy. Academy of Management Review, 8(1): p. 61-70.

Burgelman, R.A. (1991): Intraorganizational Ecology of Strategy Making and Organizational Adaptation: Theory and Field Research. Organizational Science, 2(3): p. 239-262.

Cavaleri, S. - Fearon, D. (1996): Managing in organizations that learn. Cambridge: Blackwell

Child, J. (1972): Organisational Structure, Environment and Performance: The Role of Strategic Choice. Sociology, 6(1): p. 1-22.

Crossan, M. M. - Lane, H.W. - White, R. E. (1999): An organizational learning framework: From intuition to institution. Academy of Management Review, 24(3): p. 522-537.

Cyert, R. M. - March, J. G. (1963): A Behavioral Theory of the Firm. Englewood Cliffs, N.J.: Prentice-Hall

Dobák, M. - Antal, Zs. (2010): Vezetés és szervezés. Budapest: Aula

Dobák, M. - Hortoványi, L. - Szabó, Zs. R. (2012): A sikeres növekedés és innováció feltételei. Vezetéstudomány (Budapest Management Review), 43(12): p. 40-48.

Duncan, R. B. (1972): Characteristics of Organizational Environments and Perceived Environmental Uncertainty. Administrative Science Quarterly, 17(3): p. 313-327.

Easterby-Smith, M. - Prieto, I. M. (2008): Dynamic Capabilities and Knowledge Management? An Inte- grative Role for Learning? British Journal of Management, 19(3): p. 235-249.

Eisenhardt, K. M. - Martin, J. (2000): Dynamic capabilities - what they are? Strategic. Management Journal, 21: p. 1105-1121.

Fiol, C. - Lyles, M. A. (1985): Organisational learning. Academy of Management Review, 10(4): p. 803-813.

Ford, J. D. - Ford, L. W. (1995): The role of conversations in producing intentional change in organizations. Academy of Management Review, 20(3): p. 541-570.

Garaj, E. (2008): Knowledge Development vs. Competitiveness. Development - Finance: Quarterly Hungarian Economic Review, 2(6): p. 38-46.

Garvin, D. A. (1993): Building a learning organization. Harvard Business Review, 71(4): p. 78-91.

Gelei A. (2002): An interpretive approach to organizational learning: the case of organization development. Doctoral (PhD) thesis. Budapest: Corvinus University of Budapest, Business Doctoral School

Gelei, A. (2005): A szervezeti tanulás interpretative megközelítése: „A reflektív akciótanulás” irányzata. in: Bakacsi, Gy. - Balaton, K. - Dobák, M. (eds): Változás és vezetés. Budapest: Aula Kiadó

Hannan, M. T. - Freeman, J. H. (1989): Organizational Ecology. Cambridge, MA.: Harvard Business School Press

Hortoványi, L. - Szabó, Zs. R. (2006a): Vállalati stratégiák az EU-csatlakozás idején Magyarországon. Vezetéstudomány (Budapest Management Review), 37(10): p. 10-23.

Hortoványi, L. - Szabó, Zs. R. (2006b): Pillanatfelvétel a magyarországi közép- és nagyvállalatok vállalkozási hajlandóságáról, „Versenyben a világgal 2004-2006 - Gazdasági versenyképességünk vállalati nézőpontból” címú kutatás 27. sz. múhelytanulmány. Budapest: Budapesti Corvinus Egyetem

Hortoványi, L. - Szabó, Zs. R. (2006c): Knowledge and Organization: A Network Perspective. Society and Economy, 28(2): p. 165-179.

Hortoványi, L. (2012): Entrepreneurial Management. Budapest: Aula Kiadó

Huber, G. P. (1991): Organizational learning: The contributing processes and the literatures, Organization Science, 2(1): p. 88-115.

Jyothibabu, C. - Farooq, A - Pradhan, B. B. (2010): An integrated scale for measuring an organizational learning system. The Learning Organization, 17(4): p. 303-327.

Lähteenmäki, S. - Toivonen, J. - Mattila, M. (2001): Critical aspects of organisational learning: Research at proposal for its mesurement. British Journal of Management, 12(2): p. 113-129.

Lawrence, P. - Lorsch, J. (1967): Differentiation and 
Integration in Complex Organizations. Administrative Science Quarterly, 12(1): p. 1-47.

Lee, S. - Courtney, J. - O'Keefe, R. (1992): A system of organizational learning using cognitive maps. International Journal of Management Science, 20(1): p. 23-36.

Levinthal, D. - Rerup, C. (2006): Crossing an Apparent Chasm: Bridging Mindful and Less-Mindful Perspectives on Organizational Learning. Organization Science, 17(4): p. 502-513.

Levitt, B. - March J. (1988): Organizational Learning. Annual Review of Sociology, 14.: p. 319-338.

March, J. G. - Simon H. (1958): Organizations. New York: Wiley

Mészáros, T. (2010): Régi és új elemek a stratégiai gondolkodásban. Vezetéstudomány (Budapest Management Review), 41(4): p. 2-12.

Mészáros, T. (2011): Traditional and new elements in strategic thinking. International Journal of Management Cases, 13(Special issue): p. 845-865.

Miles, R. E. -Snow, C.C.-Meyer, A.D. - Coleman, $H$. J. Jr. (1978): Organizational Strategy, Structure and Process. Academy of Management Journal, 3(3): p. 546-562.

Mintzberg, H. - Ahlstrand, B. - Lampel, J. (2009): Strategy Safari. The complete guide through the wilds of strategic management. Upper Saddle River N.J.: Prentice Hall

Nelson, R. - Winter, S. (1982): An Evolutionary Theory of Economic Change. Cambridge, MA.: Harvard University Press

Noszkay, E. (2008): A változás- és válságmenedzselés néhány elméleti és gyakorlati dilemmája, Vezetéstudomány (Budapest Management Review), 39(4): p. 24-34.

Porter, M. E. (1993): Versenystratégia, ipari ágak és versenytársak elemzési módszerei. Budapest: Akadémiai Kiadó

Rerup, C. - Levinthal, D. A. (2014): Situating Concept of Organizational Mindfulness: The Multiple Dimensions of Organizational Learning. in: Becke, G. (ed.) (2013): Mindful Change in Times of Permanent Reorganization: Organizational, Institutional and Sustainability Perspectives. Berlin: Springer: $p$. 33-49.
Schwandt, D. - Marquardt M. (2000): Organizational learning: From world-class theories to global best practices. Boca Raton: St. Lucie

Senge, P. - Kleiner, A. - Roberts, C. - Ross, R. - Roth, G. - Smith, B. (2014): The Dance of Change. The Challenges to Sustaining the Momentum in Learning Organizations. New York: Doubleday

Senge, P. M. (1990): The Fifth Discipline: The Art and Practice of the Learning Organisation. New York: Doubleday Currency

Shrivastava, P. (1983): A Typology of Organisational Learning Systems. Journal of Management Studies, 20(1): p.7-28.

Slater, S. F. - Narver, J. C. (1995): Market orientation and the learning organization. Journal of Marketing, 59(3): p. 63-74.

Smith, E. E. - Nolen-Hoeksema, S. - Fredrickson, B. L. - Loftus, G. R. (2005): Atkinson \& Hilgard Pszichológia. Budapest: Osiris Kiadó

Smith, K. G. - Cao, Q. (2007): Entrepreneurial Perspective of Firm-Environment Relationship. Strategic Entrepreneurship Journal, 1(3-4): p. 329-344.

Stata, R. (1989): Organizational Learning - The Key to Management Innovation. Sloan Management Review, Spring

Szabó, Zs. R. (2012): Stratégiai adaptáció és kettős (verseny)képesség. Magyarországon 1992 és 2000 között. Budapest: Aula Kiadó

Szabó, Zs. R. (2008): Adaptációs stratégiák a kialakuló bioetanol-iparágban. Vezetéstudomány (Budapest Management Review). 39(11): p. 54-63.

Weick, K. E. - Quinn, R. E. (1999): Organizational Change and Development. Annual Review of Psychology, 50: p. 361-386.

Weick, K.E. - Roberts, K. H. (1993): Collective mind in organizations: heedful interrelating on flight decks. Administrative Science Quarterly, 38(3): p. 357-381.

$Y e o, R . K$. (2005): Revisiting the roots of learning organization. The Learning Organization, 12(4): p. $368-382$.

Zollo, M. - Winter, S. G. (2002): Deliberate learning and the evolution of dynamic capabilities. Organization Science, 13(3): p. 339-351. 